\title{
Evaluation of physical properties of irrigated soils of Gir Somnath district of Gujarat
}

R.B. CHAUHAN AND J.V. POLARA

Received : 27.06.2014; Revised : 17.11.2015; Accepted : 30.11 .2015

\author{
MEMBERS OF RESEARCH FORUM: \\ Corresponding author : \\ J.V. POLARA, Department of \\ Agricultural Chemistry and Soil \\ Science, Junagadh Agricultural \\ University, JUNAGADH (GUJARAT) \\ INDIA \\ Email: jvpolara@jau.in \\ Co-authors : \\ R.B. CHAUHAN, Department of \\ Agricultural Chemistry and Soil \\ Science, Junagadh Agricultural \\ University, JUNAGADH (GUJARAT) \\ INDIA \\ Email : chauhanravi3612@gmail. \\ com
}

\section{Summary}

Thirty surface $(0-15 \mathrm{~cm})$ soil samples were collected from each talukas of Gir Somnath district viz., Talala, Veraval, Sutrapada, Kodinar, Gir Gadhada and Una. The physical characteristics properties of the soils were determined by using standard methods. The soils of Gir Somnath have overall values of bulk density, particle density, total porosity, MWHC and expansion varied from 1.24 to $1.45,2.07$ to $2.67 \mathrm{Mg} \mathrm{m}^{-3}, 36.96$ to $53.39,31.06$ to 56.89 and 5.54 to 35.52 per cent with mean value of $1.34,2.49 \mathrm{Mg} \mathrm{m}^{-3}, 46.00,41.91$ and 21.97 per cent, respectively.

Key words : Physical properties of soils, Bulk density, Particle density, Porosity, MWHC

How to cite this article : Chauhan, R.B. and Polara, J.V. (2015). Evaluation of physical properties of irrigated soils of Gir Somnath district of Gujarat. Asian J. Soil Sci., 10(2) : 306-308. 